Lord Franks also points out that while these two business schools would form a major reinforcement at the national level, they could deal with only a small fraction of existing and potential managers. Their effectiveness must depend in part on whether many others who are entering management are also being helped to become better at their jobs, and it was of great importance that the general body of education and training for management in Britain should continue to develop. Equally pertinent to the question of industrial training in its widest sense, he also observes that if the business school is to have a major effect, every company which sends senior men to the courses or takes on young men who have been to the school must have a continuous and coherent programme of training and, above all, an adequate management development programme. Without these much of the work of the school will be wasted.

For that reason alone even training for management at the level discussed in the Franks Report cannot be considered entirely outside the scope of the Industrial Training Bill. While here the main responsibility must lie on industry itself, the Government must make certain that the responsible Minister has the resources and staff at his disposal to ensure that all concerned are really playing their part. Persuasion is always more desirable than compulsion, but the bitter experience of the past has shown that on both sides of industry it is necessary to have sanctions in reserve if co-operation is not forthcoming and obligations are disregarded, Fortunately, unless the assurances given on all sides, especially when the Bill was debated in the House of Commons, are not to be discounted as fundamentally insincere, there is sound reason for believing that a measure so generally welcomed will be strongly supported in practice.

\section{RECORDING THE BEHAVIOUR AND PHYSIOLOGY OF ANIMALS}

\section{Bio-telemetry}

The Use of Telemetry in Animal Behaviour and Physiology in Relation to Ecological Problems. Edited by Lloyd E. Slater. (Proceedings of the Interdisciplinary Conference, New York, March 1962.) Pp. xii +372. (London and New York: Pergamon Press, 1963.) 126s. net.

$\mathrm{W}$ HENEVER we study an animal, whether we simply watch it with our two eyes, track it by the noise it makes or follow its footprints in the snow, we are in effect observing its behaviour and often obtaining information about its physiological state by observation at a distance. All instrumentation which extends or refines the performance of our distance receptors, whether microscope or telescope, camera or range-finder, pressure gauge or tape-recorder, can logically be brought under the term 'telemetry'. The term is, however, a now one coined in recent years to cover the great development in biological monitoring devices consequent on the development of electronics and traditionally carrying with it the idea of using a wircless link over a substantial distance. So it was a natural idea to bring together a number of people who were using such techniques in biological research whether in behaviour, physiology or ecology, to pool their experience and technical know-how. The results of such a conference, held in New York in March 1962, have now been published under the titlo Bio-telemetry.

No doubt it was a stimulating gathering, but the result when published turns out to bo a very mixed bag with items of greatly varying merit. One feels that some of the contributors are intoxicated with their own ingenuity and a great deal of space is given up to details of circuitry and indeed, in places, quite advanced electronic theory. Some of the writers seem prepared, on the plea that to look at an animal disturbs it, to go to almost any length to avoid actually looking at an animal themselves; and there is a widespread, sometimes almost comical, disregard of the opposite danger-one might almost say certainty-of upsetting an animal's behaviour by loading it with transmitting dovices. A good example of this is Alvin Singer's paper, misleadingly entitled "Some Solutions to the Problem of Homing". Another danger is more subtle and, therefore, even more serious. It is impossible to monitor the complete behaviour of an animal by telemetry; therefore one has to select certain features for instrumental observation. But once one has started on this course one almost certainly tends to cease direct observation and so is very likely to miss other aspects of the total behaviour which may be vitally important. The moral of this is that telemetry is seldom a safe tool except in the hands of one who is fully trained in the subtle and difficult science and art of observing and interpreting animal behaviour-in short, one who has the ethological approach.

One must immediately say that certain of the contributors are well aware of these dangers and continually pointing them out. It is this which gives much of the discussion its stimulating character. Some members (in particular D. R. Griffin) fulfil a valuable function in bringing high-flying telemetrists back to the solid ground of observation, and in slyly puncturing technical pomposities. There is a great deal of interest in the book and many suggestions and ideas for future development; and many workers who are up against the intractable problems of recording and analysing biological processes will find useful hints in fields other than their own, as a result of perusing this book. The volume commences with an amusing though somewhat irrelevant introduction by Warren McCulloch; after which the work is divided into six main sections entitled as follows: "The Potential for Telemetry in Biological Research"; "The Current State of Biological Telemetry"; and reports on "Telemetry in Animal Tracing, Orientation and Ecology"; "Studies of Animal Social Behaviour"; "Studies of Animal Physiology"; and "Studies of Physiology in Man". The production is excellent and the illustrations lavishincluding half a dozen pictures of lecturers delivering their lectures! But the price for non-American workers is fantastically high for what the book contains.

W. H. THORPE

\section{THE FARMING YEAR}

\section{Agricultural Synthesis}

The Farming Year. By Prof. A. N. Duckham. Pp. xiv +525 . (London : Chatto and Windus, Ltd., 1963.) $75 s$. net.

CHE author states that Agricultural Synthesis is intended for agricultural students, the general agriculturist, the specialist interested in wider aspects of agriculture than his own special field, the geographer, historian or natural historian broadly interested in the interaction between man and the world and, finally, parts of it should interest those responsible for initiating or directing research programmes. It would require an unusual book to satisfy all these claims, but Prof. Duckham's latest book makes stimulating reading and does represent an original approach to the subject.

Tho book is divided into a general introduction entitled "The Aseasonality of Man", and four parts entitled "Man", "Science", "Work" and "The Farming Year" respectively. Each of Parts 1-3 has its own introduction, followed by a varying number of chapters. Each chapter has its own introduction, summary and conclusions and is sub-divided 